\title{
Supervisory Sanctions against Children in Conflict with the Law
}

\author{
Andi Drie Gunawan ${ }^{1 *}$, Muhadar $^{2}$, Nur Azisa ${ }^{3}$ \\ ${ }^{1}$ Graduate Student, Faculty of Law, Hasanuddin University, Indonesia \\ ${ }^{2}$ Professor, Faculty of Law, Hasanuddin University, Indonesia \\ ${ }^{3}$ Associate Professor, Faculty of Law, Hasanuddin University, Indonesia
}

DOI: $10.36348 /$ sijlcj.2020.v03i04.003

| Received: 26.03.2020 | Accepted: 02.04.2020 | Published: 07.04.2020

*Corresponding author: Andi Drie Gunawan

\section{Abstract}

The purpose of this study is to analyze the criminal penalties and criminal liability of children, as well as the mechanism of supervisory sanctions for children in conflict with the law. This type of research is normative juridical research. The legal material used is primary legal material and secondary legal material. Data collection techniques used to obtain data and information through library research methods. Primary legal materials and secondary legal materials that have been collected and then analyzed which will later be linked to the principles, legal theories and the formulation of existing legislation and conclusions can be drawn. The results showed that the elements of criminal accountability were (1) Capable of being responsible; (2) There are errors; and (3) Absence of forgiving reasons. All three elements must be fulfilled by a child when he will be held accountable before the law. The imposition of criminal sanctions for supervision of children in conflict with the law is reviewed from the perspective of a criminal law on child protection based on Law Number 11 of 2012 concerning the Criminal Justice System for Children. The imposition of supervision criminal is based on the type of crime committed by the child.

Keywords: Children, Sanctions, Supervision.

Copyright @ 2020: This is an open-access article distributed under the terms of the Creative Commons Attribution license which permits unrestricted use, distribution, and reproduction in any medium for non-commercial use (NonCommercial, or CC-BY-NC) provided the original author and source are credited.

\section{INTRODUCTION}

Indonesia as a state of law as stipulated in Article 1 paragraph (3) of the 1945 Constitution of the Republic of Indonesia, has logical consequences that all acts of citizens, the government including law enforcement officials must be based on applicable law so there is no room for state apparatus to act in violation of existing legal provisions. Society in general often understands the law as a set of rules made by the State and binds its citizens with the mechanism of the existence of sanctions as a coercion. The purpose of law will be achieved when there is harmony between legal certainty with the benefit of law so as to produce a justice [1].

At present, the types of crimes contained in the draft Penal Code have included supervision penalties as part of the main criminal types. Supervisory sanctions are quite interesting to study because this is a new type of sanctions, which if agreed upon will be one of the types of sanctions choice applied to the Indonesian Penal Code. Supervisory sanctions are one of the main criminal types regulated in Article 65, Article 76 and Article 77 of the draft Penal Code 2019. In the explanation of the article it is explained that the emergence of the type of sanctions oversight is as an alternative sanctions deprivation of short-term independence and fines imposed by the judge to the defendant and the deprivation of short-term independence in this case is imprisonment and confinement [2].

In addition to the draft Penal Code that has included supervisory sanctions as part of the main sanctions types, there is also Law Number 11 of 2012 concerning the Criminal Justice System for Children. This law was enacted and implemented in 2014. This law enhances the previous law, namely Law Number 3 Year 1997 concerning Juvenile Court.

Lately the development of children's problems in Indonesia is increasingly complex. According to data from the Indonesian Child Protection Commission (KPAI), cases of children in conflict with the law, are the most frequently reported cases to the Indonesian Child Protection Commission. From 2011 to 2019, the number of children in conflict with the law cases reported to the Indonesian Child Protection Commission reached 11,492 cases, far higher than the reported cases of children who were caught in health 
and drug problems $(2,820$ cases $)$, pornography and cyber crime (3,323 cases), and trafficking and exploitation (2,156 cases) [3]. Data on the number of child cases is estimated to increase from year to year. If this problem is not immediately addressed, it is feared that it will cause more complex problems.

Many children come into contact with the law and many even have problems with the law. A child who is in conflict with the law or has committed a real crime due to the objective conditions or conditions surrounding the child himself and his environment.

Considering the negative impact of the crime of deprivation of liberty on the development of a child who is in conflict with the law, Law Number 11 Year 2012 concerning the Criminal Justice System for Children, offers other alternatives as a substitute for the deprivation of the crime of deprivation of liberty, one of which is a criminal oversight. But in the implementation of criminal supervision as an alternative criminal deprivation of liberty for children who are in conflict with the law so far is still less effective, bearing in mind that there are still many imprisonment sentences imposed on children in conflict with the law. Even since the enactment of Law Number 11 Year 2012 concerning the Criminal Justice System for Children, there has never been a sentence regarding the type of criminal sanctions in the form of criminal supervision of children in conflict with the law. Based on this, the problem that will be discussed in this paper is how is criminal penalties and criminal liability of children? and what is the mechanism of supervisory sanctions for children in conflict with the law?

\section{RESEARCH METHODS}

This type of research is normative juridical research. The normative juridical approach aside from referring to the legal norms contained in the statutory regulations and court decisions and legal norms that exist in society, also sees synchronization of a rule with other rules in a hierarchical manner, whereas an empirical juridical approach is a different approach. Seeing the reality of law in society, this empirical juridical approach is an approach used to look at legal aspects of social interaction in society [4]. The legal material used is primary legal material and secondary legal material. Data collection techniques used to obtain data and information are done through library research methods, namely collecting data obtained from literary sources, scientific work, legislation namely Law Number 11 of 2012 concerning the Criminal Justice System for Children and other sources that have something to do with the problem being investigated as a theoretical foundation. Primary legal materials and secondary legal materials that have been collected and then analyzed which will later be associated with the principles, legal theories and the formulation of existing legislation and conclusions can be drawn to answer the problems examined.

\section{RESULTS AND DISCUSSION Criminal Penalties and Criminal Liability of Children}

Criminal action is usually defined as the stage of determining sanctions and also the stage of giving sanctions in criminal law. Criminal meaning is punishment. Criminalization as an act against a criminal, can be justified normally not primarily because the conviction contains positive consequences for the convicted, victim and also the community. Criminal punishment is not because they have done evil but so that perpetrators of crimes no longer do evil and others are afraid of committing similar crimes.

That means the punishment is not intended as an attempt to revenge but as an effort to foster a criminal as well as preventive efforts against the occurrence of similar crimes [5]. The moderate view maintained by Marc Ancel (France) who named the flow as "Defense Sociale Nouvelle" or "New Social Defense" or "New Social Protection". According to him, each community requires a social order, which is a set of regulations that are not only in accordance with the needs for a common life, but in accordance with the aspirations of the community members in general. Therefore, the large role of criminal law is an inevitable requirement for a legal system [6].

Some moderate view concepts put forward by Marc Ancel are [6]:

1. A moderate view aims at integrating ideas or conceptions of community protection into a new conception of criminal law;

2. The protection of individuals and society depends on the precise formulation of criminal law, and this is no less important than the life of the community itself;

3. In using the criminal law system, this school rejects the use of fiction and juridical techniques that are independent of social reality. This is a reaction to the legism of the classical school.

Criminal theory according to Herbert L. Packer states that there are two conceptual views, each of which has different moral implications, namely a retributive view and a utilitarian view [7]. The retributive view presupposes punishment as a negative reward for deviant behavior committed by the community members so that this view sees pemindinan only as retaliation for mistakes made on the basis of their respective moral responsibilities. This view is said to be backward-looking.

The tillitarian view sees punishment in terms of its benefits or uses where what is seen is the situation or circumstances that wish to be produced by the conviction. On the one hand, punishment is intended to improve the attitude or behavior of the convicted person 
and on the other hand the punishment is also intended to prevent others from the possibility of committing similar acts. This view is said to be forward-looking and at the same time has deterrence.

Criminal liability in foreign terms is referred to as thebaekheardheid or criminal responsibility which leads to the criminalization of the offender with a view to determining whether a suspect or defendant can be held responsible for a crime or not. To be able to convict the offender, it is required that the crime committed does meet the elements of offense specified in the Act. Seen from the point of occurrence of prohibited acts, a person will be held accountable for those actions if the act is against the law and there is no justification for exclusion or negation of the unlawful nature for the crime he committed. And from the standpoint of the ability to take responsibility, only someone who is capable of being held responsible may be held accountable for his actions [8].

Children as young people are the successors of the ideals of the struggle of the nation and human resources for national development. A child needs guidance and special attention, especially their parents and the government to achieve maximum physical, mental and spiritual development [9]. In order for every child to be able to assume these responsibilities, he needs to get the widest opportunity to grow and develop optimally, both physically, mentally and socially, and have a noble character, so that protection efforts are needed to realize the welfare of children by providing guarantees for fulfillment of their rights and the existence of treatment without discrimination [10]. The elements of criminal liability are:

1. Able to be responsible;

2. There is an error; and

3. Absence of forgiving reason.

All three elements must be fulfilled by a child when he will be held accountable before the law. Law Number 11 Year 2012 concerning the Criminal Justice System for Children uses the Restorative justice approach, namely the settlement of criminal cases disputes involving the perpetrators, victims, the perpetrators/victims and other relevant parties to jointly seek a fair solution by emphasizing recovery in its original state, not retaliation [11].

\section{Supervisory Sanctions}

Montesquieu states that a good form of legislation should endorse crime prevention rather than punishment [12]. Formal criminal law cannot function without violations of material norms of criminal law (criminal acts) [13]. After the issuance of Law Number 11 Year 2012 replacing Law Number 3 Year 1997 concerning Juvenile Courts, the Law on the Criminal Justice System for Children has specifically regulated the material criminal law, formal criminal law and criminal implementation law for children who commit a crime or in this law referred to as a child in conflict with the law. The Criminal Justice System for Children Law, hereinafter referred to as the SPPA Law, is a special law (lex specialis) of general law (lex generalis) contained in the Penal Code (KUHP) and the Criminal Procedure Code (KUHAP).

The understanding of children in the Act is given different restrictions from the previous law. In the SPPA Law regulated in Article 1 point 2, children who are in conflict with the law are children who are in conflict with the law, children who are victims of criminal acts and children who are witnesses of criminal acts. The next item explains that children who are in conflict with the law, hereinafter referred to as children, are children who are 12 (twelve) years old, but not yet 18 (eighteen) years old who are suspected of committing criminal offenses. The age limit in the SPPA Law differs from the age limit stipulated in the juvenile court Law previously in Law Number 3 Year 1997 it is explained that what is meant by a child is a person who in a naughty case has reached the age of 8 (eight) years but has not yet reached um 18 (eight) twelve years and have never been married. The bad boy in this law is:

a. Children who commit crimes; or

b. Children who commit acts that are prohibited for children both according to the laws and regulations and according to other legal regulations that live and apply in the community concerned.

The juvenile justice system is the whole process of resolving cases of children dealing with the law, starting from the investigation stage to the guidance stage after undergoing the crime. The formulation of criminal sanctions and actions in the SPPA Law shows that the juvenile justice system has adopted a double track system. In other words, the SPPA Law has explicitly governed the types of criminal sanctions and sanctions at the same time. According to Muladi, the use of the two-lane system (Zwiepurigkeit) was a consequence of the adoption of the Neo Classical school [14].

Rights is something that is inherent in every human being, and rights can be applied in every scope of life [15]. In the SPPA Law, sanctions for children in conflict with the law consist of criminal sanctions and sanctions actions. In Article 71 of the SPPA Law, the main sanctions consists of:

a. Criminal warnings, namely minor crimes that do not result in restrictions on children's freedom;

b. Criminal conditions include: coaching outside the institution, community service or supervision;

c. Work training;

d. Coaching in institutions;

e. Jail. 
The additional sanctions consist of:

a. Expropriation of profits derived from criminal acts; or

b. Fulfillment of customary obligations

While sanctions in the form of actions are regulated in Article 82, actions that can be imposed on children include:
a. Returns to parents/guardians;
b. Submission to someone;
c. Care in a mental hospital;
d. Treatment at LPKS;
e. Obligation to receive formal education and/or training conducted by the government or private body;
f. Revocation of driving license; and/or
g. Repairs due to criminal acts.

Supervisory sanctions are one of the main crimes that are threatened by children who commit a crime. Supervisory sanctions are included in the sanction's category on condition. Sanctions conditions can be imposed by a judge in the case of imprisonment which is up to 2 (two) years. In a court decision regarding a crime, the general conditions and special conditions are determined.

The general condition is that the child will not commit another crime while serving a criminal term with the condition. Whereas the special requirement is to do or not do certain things that are determined in the judge's decision while still paying attention to the freedom of the child. The criminal period with special conditions is longer than the criminal period with general conditions.

The term of the criminal period with a maximum term of 3 (three) years. During serving the criminal period on condition, the public prosecutor conducts supervision and the community counselor conducts guidance so that the child occupies the stipulated requirements. During serving a criminal condition, the child must attend 9 (nine) years compulsory education.

In the SPPA Law does not explicitly regulate how the implementation of this criminal oversight. Supervisory sanctions are a new sanction regulated in the SPPA Law even though in the latest Penal Code Draft 2019 the latest criminal oversight is one of the main crimes that are threatened.

In Article 79 of the Penal Code Draft it is stated that a defendant who commits an offense threatened with imprisonment for a maximum of 7 (seven) years may be subject to supervisory sanctions. Supervisory sanctions can be handed down to the defendant given his personal circumstances and actions. Supervisory sanctions are imposed for a maximum period of 3 (three) years.
In imposing supervisory sanctions, conditions can be determined based on Article 80 paragraph (3) of the Criminal Code Draft, i.e.:

1. The convict will not commit a criminal offense;

2. The convict within a certain period that is shorter than the criminal period of supervision, must replace all or part of the losses arising from the criminal offenses committed and/or;

3. The convicted person must commit an act or not do certain acts without reducing religious freedom and political freedom.

Supervision is carried out by the correctional center at the ministry that organizes government affairs in the field of law and human rights. If during the supervision of a convicted person violates the law, the correctional center at the ministry that carries out government affairs in the field of law and human rights can propose to the supervisory judge to extend the period of supervision which does not exceed the maximum 2 (two) periods of supervision that have not yet been served.

If during the supervision of the convicted person shows good behavior, the socialization center at the ministry that conducts government affairs in the field of law and human rights can propose to the supervisory judge to shorten the period of supervision. The supervising judge can change the determination of the period of supervision after hearing the parties.

Furthermore, it is regulated further in Article 81 of the Penal Code Draft that if a convicted person while undergoing criminal supervision commits a criminal offense and is convicted of a crime not a capital punishment or a non-prison sentence, then the supervisory sanctions is still carried out. If the convict is sentenced to imprisonment then the supervisory sanctions is postponed and re-implemented after the convict has finished serving a prison sentence.

In the explanation of the SPPA Law, it is understood that what is meant by supervisory sanctions is a sanction specifically imposed on children, namely supervision conducted by the public prosecutor on children's behavior in daily life at the child's home and providing guidance carried out by the social counselor.

In Article 77 of the SPPA Law it is stipulated that supervisory sanctions can be imposed on children for a minimum of 3 (three) months and a maximum of 2 (two) years. In the event that a child is sentenced to criminal supervision, the child is placed under the supervision of the public prosecutor and is guided by the social counselor.

According to Muladi, the term probation/supervisory sanctions in the modern sense has a meaning as a system that seeks to carry out rehabilitation of someone who is proven to have 
committed a crime, by returning it to the public during the period of supervision.

Muladi said that there were two approaches in the effort to find sanctions type formulations as an alternative to sanctions deprivation of liberty, i.e [16]:

1) An approach that sees criminal alternatives as deprivation of liberty (prison) as an alternative sanction, namely sanctions that can replace sanctions imprisonment, where these alternative sanctions can only be used and accepted when the sanctions can serve the purpose of punishment and imprisonment is deemed unnecessary;

2) An approach which states that alternative sanctions are an effort to achieve the goals of punishment where the criminal penalties for the purpose of punishment cannot even be achieved.

Speaking of the supervisory sanctions, inevitably the problem will not be separated from the conditional criminal arrangement, in Wetboek van Straftrecht 1915, because it seems that this criminal oversight is an increase in conditional criminal conduct. The growth of conditional criminal institutions in Indonesia cannot be separated from the growth of institutions such as those that preceded it in the United States and other states [17].

Based on theoretical and practical studies with the development of criminal surveillance carried out by several countries in the world, is an alternative to the crime of deprivation of liberty imposed by the judge. In England and in Western Europe, France and Belgium. The first legal regulation on probation took place in Massachusetts in 1878 which allowed for the postponement of a criminal sentence by placing the criminal in probation. This was gradually accepted by other states. Furthermore, this was also followed by Britain.

In mainland Europe after going through sharp differences of opinion among scholars, a form of conditional criminal delay has been accepted called "soursis simple" ie in France in 1891 and in Belgium in 1888. This institution is more a delay in the implementation of a crime rather than a delay criminal conviction like a probation system. Another difference is that the conditional criminal adjournment institution does not at all require supervision or assistance to the convicted person.

\section{CONCLUSION}

The elements of criminal accountability were (1) Capable of being responsible; (2) There are errors; and (3) Absence of forgiving reasons. All three elements must be fulfilled by a child when he will be held accountable before the law. The imposition of criminal sanctions for supervision of children in conflict with the law is reviewed from the perspective of a criminal law on child protection based on Law Number 11 of 2012 concerning the Criminal Justice System for Children. The imposition of supervision criminal is based on the type of crime committed by the child.

\section{REFERENCES}

1. Eka, R. I. (2018). Pelatihan Kerja Sebagai Sanksi Pidana Terhadap Anak Yang Berkonflik Dengan Hukum (Job Training as Criminal Sanctions for Children in Conflict with the Law), Journal Rechtidee, 13(1):23.

2. Gatot, S. (2016). Relevansi Kebijakan Penetapan Pidana Kerja Sosial Dalam Sistem Pemidanaan di Indonesia (The Relevance of the Criminal Determination Policy in the Criminal System in Indonesia), Jurnal Hukum Fakultas Hukum Universitas Ahmad Dahlan, 13.

3. https://amp.suara.com/health/2019/07/23/071000/a nak-berhadapan-dengan-hukum-potret-buramperlindungan-anak-di-indonesia accessed on 21 October 2019

4. Ali, Z. (2009). Metode Penelitian Hukum (Legal Research Methods), Jakarta: Sinar Grafika, 175.

5. Amir, I. (2012). Asas-Asas Hukum Pidana (Criminal Law Principles). Yogyakarta: Rangkang Education Offset, 95.

6. Marc, A. (1965). Social Defence, Modern Approach to the Criminal Problem, London: Roatledge \& Paul Keagen, 74.

7. Herbert, L. P. (1968). The Limits of The Criminal Sanction, Stanford: Stanford University Press, 9.

8. Audyna, M. M. (2013). Pertanggungjawaban Pidana Pedofilis dalam Tindak Pidana Pencabulan Terhadap Anak (Liability of Pedophilic Crimes in the Criminal Act of Sexual Abuse of Children), Thesis of Postgraduate Program in Legal Studies, Makassar: Universitas Hasanuddin, 21-22.

9. Sani, A., Muhammad, R. A., \& Din, M. (2015). Pemidanaan anak menurut konsepsi hukum islam dan hukum pidana indonesia. Jurnal Ilmu Hukum, 3(3):10

10. Bilher, H. (2013). Penerapan Sanksi Pidana Bagi Pelaku Tindak Pidana Anak Kajian Putusan Nomor 50/Pid.B/2009/PN.Btg (Application of Criminal Sanctions for Child Criminal Acts Study of Decision Number 50/Pid.B/2009/PN.Btg). Jurnal Yudisial, 6(1): 65.

11. Lembong, A. G. (2014). Kajian Hukum Terhadap Sistem Pemidanaan Anak Menurut Undangundang No. 11 Tahun 2012. Lex Crimen, 3(4):13.

12. Muhadar, \& Audyna, M. M. (2016). Kriminologi: Suatu Pengantar (Criminology: An Introduction), Makassar: Pusat Kajian Media dan Sumber Belajar, LKPP Universitas Hasanuddin, 3.

13. Andi, S., \& Nur, A. (2016). Hukum Pidana (Criminal Law), Makassar: Pustaka Pena Press, 3. 
14. Muladi. (2002). Hak Asasi Manusia Politik dan Sistem Peradilan Pidana (Political Human Rights and Criminal Justice System), Semarang: Badan Penerbit Universitas Diponegoro, 156.

15. Kadarudin, K. (2015). Legal Guarantees and Inconsistency of State Recognition to the Right of Religion/Belief in Indonesia. Hasanuddin Law Review, 1(1), 1-16.

16. Muladi. (1990). Proyeksi Hukum Pidana Materiil di Masa Datang (Projection of Material Criminal
Law in the Future), Semarang, Speech of Inauguration of Professor of Law at UNDIP, 3.

17. Audyna, M. M. (2018). Hakikat dan Fungsi Sanksi Dalam Pencegahan dan Penanggulangan Tindak Pidana di Bidang Pendidikan di Indonesia (The Essence and Function of Sanctions in Prevention and Management of Criminal Acts in the Field of Education in Indonesia), Makassar, Dissertation: Doctor of Law Program, Hasanuddin University, 291. 